\title{
Proximate Composition and Heavy Metal Content of Three Class Sizes of the Clam Senilia senilis from the Andoni River, Niger Delta, Nigeria.
}

\author{
Umesi, N. ${ }^{1 *}$, Oguzor, N. S. ${ }^{2}$, Ezekiel, P. O. ${ }^{3} \&$ Dike, C. I. ${ }^{4}$ \\ ${ }^{I}$ Department of Biology Education. Federal College of Education (Technical) Omoku, Nigeria. \\ ${ }^{2}$ Department of Agronomy, Michael Okpara University of Agriculture, Umudike, Nigeria. \\ ${ }^{3}$ Department of Agricultural Education, Federal College of Education (Technical) Omoku, Nigeria. \\ ${ }^{4}$ Institute of Geosciences \& Space Technology, Rivers State University of Science \& Technology, Nigeria.
}

\begin{abstract}
The proximate composition and heavy metal content of the clam Senilia senilis from the Andoni River was investigated. Samples were categorized into three class sizes: small $(<30 \mathrm{~mm})$, medium $(30-50 \mathrm{~mm})$, and large (> $50 \mathrm{~mm}$ ) each with 10 sampling units for each class size. Differences across class size were significant for carbohydrate, protein, lipid, and fiber contents but not ash and moisture contents. Effect of class size on proximate composition of soft tissues of clams was more pronounced in carbohydrate and lipid contents relative to protein and fiber contents, with mean values of carbohydrate and lipid generally higher in largesized clams compared to small-sized and medium-sized clams. Among the heavy metals, variations in mean $\mathrm{Cu}$ and $\mathrm{Zn}$ levels in $\mathrm{S}$. senilis were minimal compared to $\mathrm{Cd}$ and $\mathrm{Pb}$ in which large-sized clams also had higher mean values than small-sized clams. The chances of uptake of $\mathrm{Cd}$ and $\mathrm{Pb}$ in higher trophic levels of the food chain are higher following consumption of large-sized clams, since the concentrations of these heavy metals appear to be higher in large-sized clams compared to small-sized and medium-sized individuals.
\end{abstract}

Keywords: Proximate, Composition, Heavy Metal, \& Clams

\section{Introduction}

Nigeria's endowment with a maritime area of $46,300 \mathrm{~km}^{2}$, an Exclusive Economic Zone (EEZ) area of $210,900 \mathrm{~km}^{2}$ and inland waters of 12.5 million ha clearly indicates that the country has vast potentials for fisheries development (Woke et al., 2016). Despite this, the current production level of fish of 400,000 metric tons in Nigeria is at a 50\% deficit to meet the country's increasing fish needs per annum of at least 1.5 million metric tons. At the root of this problem is Nigeria's growing population which is increasing at an exponential pace and is currently estimated to be approximately 170 million people. Consequently, fishery researchers in Nigeria are beginning to turn their attention to additional sources of protein other than fish, including researches conducted on the nutritional values of the African bull frog Pyxicephalus adspersus (Daniel et al., 2016), mangrove oysters Crassostrea gasar (Woke et al., 2016), and the crab Uca tangeri (Udo and Arazu, 2012).

Among environmental pollutants, metals are of particular concern due to their potentially toxic effect and ability to accumulate in the tissues of aquatic biota (Censi et al., 2006). Aquatic biota take up heavy metals directly from water, sediment and food with concentrations in tissues sometimes reaching levels higher than those detected in the ambient environment (Labonne et al., 2001). Amisah et al. (2009) reported mean values of zinc as high as $23 \mu \mathrm{g} / \mathrm{g}$ and $42 \mu \mathrm{g} / \mathrm{g}$ in soft tissues of small-sized clams (Galatea paradoxa) from the Volta Estuary, Ghana. Murtala et al. (2012) investigated bioaccumulation of cadmium, nickel, chromium, cobalt and lead in fish samples of Hydrocynus forskahlii, Hyperopsis bebe occidentalis and Clarias gariepinus) from Ogun Estaury, Nigeria while Dimari and Hati (2009) reported mean cadmium values of $0.09 \pm 0.06 \mu \mathrm{g} / \mathrm{g}$ (Tilapia gallier) and $0.10 \pm 0.05 \mu \mathrm{g} / \mathrm{g}$ (Clarias lazera) in intestines of fish samples from Lake Alau in South Eastern Maiduguri, Nigeria.

Different species of organisms used in biomonitoring have been shown to accumulate heavy metals at different rates (Adeyeye et al., 1996). Bivalves for instance are effective biomonitors and have been widely used for purposes of heavy metal monitoring in various studies conducted around the globe (Phillips and Yim, 1981; Ferreira et al, 2004; Otchere, 2003; Woke et al, 2016). Like all bivalves, Senilia senilis can also accumulate heavy metals in their tissues at concentrations which may be higher than those measured in the ambient environment (El Shenawy, 2002).

Over the last decade, studies have been conducted to investigate the proximate composition and heavy metal content of a wide variety of commercially important and edible aquatic fauna. Some of these studies include investigations on tilapia (Bombata-Fashina et al., 2013), edible frog (Cagiltay et al., 2014; Daniel et al.,

*Correspondence: ndbc_umesi@yahoo.com 
2016), and oysters (Woke et al., 2016). At the Andoni River in the Niger Delta, S. senilis are harvested and consumed regardless of their sizes. The sizes captured and sold at the Kaa Waterside Market was found to range from $<30 \mathrm{~mm}$ to $>50 \mathrm{~mm}$. Woke et al (2016) have shown that different class sizes of the bivalve Crassostrea gasar accumulate heavy metals in varying quantities. Among the indigenous people of the Niger Delta, there are size-specific preferences in consumption of clams. It is, however, unclear which class size of S. senilis accumulates greater quantities of heavy metals in their soft tissues. The present study, therefore, focuses on the proximate composition and heavy metal content (cadmium, copper, lead, and zinc) of the clam Senilia senilis from the Andoni River, Niger Delta, Nigeria. This marine bivalve was chosen for this study because it is a delicacy which features prominently in diets of Niger Delta and is widely sold in many fish markets in Nigeria.

\section{Study Design}

\section{Materials And Methods}

The Kaa Waterside Market lies in latitude $4^{\circ} 34.18^{\prime} \mathrm{N}$ and longitude $7^{\circ} 22.10^{\prime} \mathrm{E}$ in Khana Local Government Area of Rivers State, Southern Nigeria and represents an important landing site of a wide variety of fin- and shell-fishes caught by local fishermen from the Andoni River, Rivers State, Nigeria. Although there appears to be some obvious size-specific preferences in the consumption of clams in the Niger Delta, there is a dearth of information on the class size of $S$. senilis which accumulates greater quantities of heavy metals in soft tissues. In this study, different class sizes of the clam Senilia senilis from the Andoni River were analysed for proximate composition (ash, moisture, carbohydrate, protein, lipid, and fiber content) and heavy metal content (cadmium, chromium, copper, mercury, lead, zinc, and arsenic).

\section{Collection of Samples}

Clams are well known as seafood, sources of animal protein, and are commonly sold in most fish markets in Nigeria, especially those located close to coastal areas. On January 5, 2015, samples of the clam Senilia senilis from the Andoni River were purchased from fish sellers in landing sites at the Kaa Waterside Market to reflect the three dominant groups or class sizes of small- $(<30 \mathrm{~mm})$, medium- $(30-50 \mathrm{~mm})$, and large-sized (>50 $\mathrm{mm}$ ) individuals found in the natural population of clams in the Andoni River (Table 1). Over 15 identical sampling units (i.e. similar shell length) were collected in each of the nominal categories of small-, medium-, and large-sized clams.

\section{Laboratory Analyses}

In the laboratory, samples of $S$. senilis were first cleansed to remove mud and any debris and then washed with distilled water. Samples were then categorized into three class sizes each with 10 sampling units for the small $(<30 \mathrm{~mm})$, medium $(30-50 \mathrm{~mm})$, and large $(>50 \mathrm{~mm})$ class size categories, based on shell length ( $\mathrm{mm}$ ) (Table 1). Soft tissues of S. senilis were extracted from their shells using a sterile stainless steel knife as recommended in previous studies (Koh et al., 2011; Madkour et al., 2011; Woke et al., 2016). Soft tissues of $S$. senilis were dried by thinly spreading them in a hot-box oven at a temperature of $105^{\circ} \mathrm{C}$ for $48 \mathrm{~h}$ (FashinaBombata and Megbowon, 2012; Woke et al., 2016), until they were sufficiently dry to be ground. Porcelain mortar and pestle were used to grind sampling units of each class size to fine powdery form and then screened through a sieve of $2 \mathrm{~mm}$ mesh size (Murtala et al., 2012) for analyses of proximate composition and heavy metal content.

Table 1 Mean class size distribution of the clam Senilia senilis (mean \pm SE, $n=10$ ) caught by artisanal fishermen from the Andoni River.

\begin{tabular}{|l|l|l|l|}
\hline \multirow{2}{*}{} & \multicolumn{2}{|l|}{ Shell Length $(n=10)$} & Large $(>50 \mathrm{~mm})$ \\
\cline { 2 - 4 } & Small $(<30 \mathrm{~mm})$ & Medium $(30-50 \mathrm{~mm})$ & 65.27 \\
\hline Mean & 30.91 & 43.85 & 1.16 \\
\hline
\end{tabular}

\section{Proximate Composition}

Proximate analysis was carried out in two (2) replicates according to procedures described by Allen et al. (1974) in Chemical Analysis of Ecological Materials. Ash content was determined by ashing samples in an electric muffle furnace at $500^{\circ} \mathrm{C}$ for $3 \mathrm{~h}$. Moisture content was determined by heating $1 \mathrm{~g}$ oven-dried finely ground sample in a hot box oven at $105^{\circ} \mathrm{C}$ to a constant dry weight. Protein content was determined by the Kjeldahl method in which the total nitrogen content of the sample was first estimated from which crude protein content was estimated by multiplying by the conventional factor of 6.25 (i.e. $\% \mathrm{~N} \mathrm{x} \mathrm{6.25).} \mathrm{Lipid} \mathrm{was} \mathrm{estimated}$ by the batch solvent extraction technique in which lipid was extracted using diethyl ether as solvent and the lipid content of sample determined by evaporating the solvent (Fashina-Bombata and Megbowon, 2012). The carbohydrate content was estimated as the Nitrogen-Free-Extract (NFE) by subtracting the sum of the weights of protein, fiber, and ash from the total dry matter of sample. 


\section{Heavy Metals}

Acid digestion of samples was carried out according to procedures described in Allen et al. (1974). Approximately $1 \mathrm{~g}$ oven-dried, ground and sieved sample was weighed into a 100ml kjeldahl flask to which was added $1 \mathrm{ml} 60 \%$ perchloric acid $\left(\mathrm{HCIO}_{4}\right), 5 \mathrm{ml}$ nitric acid $\left(\mathrm{HNO}_{3}\right)$ and $0.5 \mathrm{ml}$ sulphuric acid $\left(\mathrm{H}_{2} \mathrm{SO}_{4}\right)$. The flask was swirled gently and then digested slowly at moderate heat, increasing later. Sample was digested for 10-15 minutes and was set aside to cool after the appearance of white fumes. Sample was then filtered (No. 44 paper) into $50 \mathrm{ml}$ volumetric flask and diluted to volume, and used for the determinations of the heavy metals cadmium, chromium, copper, mercury, lead, zinc, and arsenic using the atomic absorption spectrophotometer.

\section{Data Analysis}

Data generated from the study were analysed using the Data Analysis Toolpak of the Microsoft Excel. Descriptive statistics (means and standard errors) were used to depict trends in proximate composition and heavy metal content of the animals used in the study. Analysis of variance (ANOVA) was used to test for significant differences in means in proximate composition as well as heavy metal content of the animals at the 95\% significance level. Where differences in ANOVA were significant, the Tukey Multiple Range Test was used as basis for distinguishing mean differences which were significantly different (Fowler et al., 1998).

\section{Proximate Composition}

\section{Results}

Results showing means and standard errors of ash content of Senilia senilis from the Andoni River are presented in Table 2 below. A slight variation was observed in ash content which ranged from a minimum in small-sized clams $(2.32 \pm 0.16 \%)$ to a maximum in large-sized clams $(3.48 \pm 0.28 \%)$. A similar pattern was observed in moisture content of the bivalves, with large-sized clams recording mean moisture content value $(4.65 \pm 0.33 \%)$ that was slightly higher than that accounted for by small-sized individuals $(3.29 \pm 0.45 \%)$. These slight variations in ash and moisture contents of $S$. senilis were, however, not found to be significant by results of ANOVA $(p>0.05$, Table 3$)$.

On the other hand, obvious differences in carbohydrate, protein, lipid, and fiber contents were observed in soft tissues of $S$. senilis in which mean values generally increased from a minimum in small-sized clams to peak values in large-sized individuals (Table 2). The carbohydrate content of large-sized clams was nearly 10 times as high as that of small-sized clams while that of medium-sized clams was at least 7 times higher than that of small-sized individuals. The result of ANOVA on carbohydrate content of S. senilis was found to be significant $\left(\mathrm{F}_{2,3}=476.386, p<0.05\right.$, Table 3$)$. There was significantly higher carbohydrate content in largesized clams compared to small-sized clams (Tukey, $p<0.05$ ).

A similar range of mean values were also observed in protein $(28.06 \pm 0.34-39.51 \pm 0.19 \%)$, lipid $(2.14 \pm 0.03-5.55 \pm 0.07 \%)$, and fiber $(9.47 \pm 0.29-14.36 \pm 0.24 \%)$ in which mean content generally increased from minimum values in small-sized individuals to peak values in large-sized individuals (Table 2). ANOVA found differences which were significant in mean content of protein $\left(\mathrm{F}_{2,3}=343.82, p<0.05\right)$, lipid $\left(\mathrm{F}_{2,3}=1087.757, p<0.05\right)$, and fiber $\left(\mathrm{F}_{2,3}=55.874, p<0.05\right)$ (Table 3). For these parameters, there were significantly higher content in large-sized clams, compared to small-sized clams. Medium-sized clams showed mean protein, lipid, and fiber content values that were significantly higher than small-sized clams but not largesized clams (Tukey, $p<0.05$ ).

Table 2 Proximate composition (mean $\pm \mathrm{SE}, \mathrm{n}=2$ ) of tissues of 3 class sizes of Senilia senilis from the Andoni River.

\begin{tabular}{|l|l|l|l|l|l|l|}
\hline \multirow{2}{*}{ Class Size } & \multicolumn{5}{|l|}{ Proximate Composition (\%) } & \multicolumn{2}{l|}{} \\
\cline { 2 - 7 } & Ash & Moisture & Carbohydrate & Protein & Lipid & Fiber \\
\hline Small & $2.32 \pm 0.16$ & $3.29 \pm 0.45$ & $4.33 \pm 0.12$ & $28.06 \pm 0.34$ & $2.14 \pm 0.03$ & $9.47 \pm 0.29$ \\
\hline Medium & $3.00 \pm 0.24$ & $3.32 \pm 0.15$ & $11.36 \pm 0.08$ & $31.92 \pm 0.38$ & $4.22 \pm 0.04$ & $12.02 \pm 0.42$ \\
\hline Large & $3.48 \pm 0.28$ & $4.65 \pm 0.33$ & $14.22 \pm 0.38$ & $39.51 \pm 0.19$ & $5.55 \pm 0.07$ & $14.36 \pm 0.24$ \\
\hline
\end{tabular}

Table 3 One-way analysis of variance on proximate composition (\%) of Senilia senilis from the Andoni River.

\begin{tabular}{|l|l|l|l|l|}
\hline Composition & $d f$ & $M S$ & $F$ & $P$-value \\
\hline Ash & 2 & 0.679 & 6.208 & $>0.05$ \\
\hline Moisture & 2 & 1.211 & 5.415 & $>0.05$ \\
\hline Carbohydrate & 2 & 51.847 & 476.386 & $<0.05^{*}$ \\
\hline Protein & 2 & 67.870 & 343.820 & $<0.05^{*}$ \\
\hline Lipid & 2 & 5.892 & 1087.757 & $<0.05^{*}$ \\
\hline Fiber & 2 & 11.939 & 55.874 & $<0.05^{*}$ \\
\hline *Significant at $p<0.05$ & & & \\
\hline
\end{tabular}




\section{Heavy Metal Content}

The means and standard errors of cadmium (Cd) content in soft tissues of Senilia senilis are presented in Table 4. Mean Cd values ranged from a minimum of $0.04 \pm 0.00 \mu \mathrm{g} / \mathrm{g}$ (small-sized clams) to a maximum of $0.11 \pm 0.01 \mu \mathrm{g} / \mathrm{g}$ (large-sized clams). ANOVA on Cd was significant $\left(\mathrm{F}_{2,3}=129.00, p<0.05\right.$, Table 5). There was significantly higher $\mathrm{Cd}$ content in large-sized clams compared to small-sized clams (Tukey, $p<0.05$ ).

Mean copper $(\mathrm{Cu})$, lead $(\mathrm{Pb})$, and zinc $(\mathrm{Zn})$ contents in soft tissues of S. senilis showed similar pattern as $\mathrm{Cd}$ across the three class sizes in which mean values also varied from a minimum in small-sized clams to a maximum in large-sized individuals. The range of mean values obtained for $\mathrm{Cu}, \mathrm{Pb}$, and $\mathrm{Zn}$ were $8.03 \pm 0.19-$ $16.39 \pm 0.11 \mu \mathrm{g} / \mathrm{g}, 0.09 \pm 0.00-0.93 \pm 0.02 \mu \mathrm{g} / \mathrm{g}$, and $20.55 \pm 0.18-25.22 \pm 0.20 \mu \mathrm{g} / \mathrm{g}$ respectively (Table 4). Results of ANOVA on $\mathrm{Cu}\left(\mathrm{F}_{2,3}=264.033\right), \mathrm{Pb}\left(\mathrm{F}_{2,3}=1352.167\right)$, and $\mathrm{Zn}\left(\mathrm{F}_{2,3}=216.740\right)$ were all significant $(p$ $<0.05$, Table 5). In a decreasing order of magnitude, the concentrations of the four heavy metals followed the trend: large-sized clams > medium-sized clams > small-sized clams. The concentrations of the various heavy metals in medium-sized clams were found to be significantly higher than values recorded in small-sized clams, but lower compared to those large-sized clams (Tukey, $p<0.05$ ).

Table 4 Concentrations (mean $\pm \mathrm{SE}, \mathrm{n}=2$ ) of heavy metals $(\mu \mathrm{g} / \mathrm{g})$ in tissues of 3 class sizes of Senilia senilis from the Andoni River.

\begin{tabular}{|c|c|c|c|c|}
\hline \multirow[t]{2}{*}{ Class Size } & & \multicolumn{2}{|c|}{ Heavy Metal Content $(\mu g / g)$} & \\
\hline & $\mathrm{Cd}$ & $\mathrm{Cu}$ & $\mathrm{Pb}$ & $\mathrm{Zn}$ \\
\hline Small & $0.04 \pm 0.00$ & $8.03 \pm 0.19$ & $0.09 \pm 0.00$ & $20.55 \pm 0.18$ \\
\hline Medium & $0.08 \pm 0.00$ & $11.71 \pm 0.39$ & $0.22 \pm 0.01$ & $23.37 \pm 0.05$ \\
\hline Large & $0.11 \pm 0.01$ & $16.39 \pm 0.11$ & $0.93 \pm 0.02$ & $25.22 \pm 0.20$ \\
\hline
\end{tabular}

Table 5 One-way analysis of variance on heavy metal content $(\mu \mathrm{g} / \mathrm{g})$ of Senilia senilis from the Andoni River.

\begin{tabular}{|l|l|l|l|l|}
\hline Heavy Metal Content & $d f$ & $M S$ & $F$ & $P$-value \\
\hline $\mathrm{Cd}$ & 2 & 0.002 & 129.000 & $<0.05^{*}$ \\
\hline $\mathrm{Cu}$ & 2 & 35.068 & 264.033 & $<0.05^{*}$ \\
\hline $\mathrm{Pb}$ & 2 & 0.406 & 1352.167 & $<0.05^{*}$ \\
\hline $\mathrm{Zn}$ & 2 & 11.086 & 216.740 & $<0.05^{*}$ \\
\hline$*$ Significant at $p<0.05$ & & & \\
\hline
\end{tabular}

\section{Discussion}

The results of ash content of Senilia senilis obtained in this study were in agreement with Woke et al. (2016) who reported mean values of ash content ranging from $2.63-3.07 \%$ in the mangrove oyster Crassostrea gasar from the Andoni River. Daniel et al. (2016) also reported a range of mean values in Pyxicephalus adspersus $(4.02 \pm 0.51-5.98 \pm 0.61 \%)$ and Oreochromis niloticus $(4.02 \pm 0.51-5.98 \pm 0.61 \%)$ from ARAC in Aluu, Port Harcourt, that were consistent with the range of values recorded in clams in the present study. The mean moisture content of $S$. senilis recorded were several orders of magnitude lower than the values reported by Daniel et al. (2016) in Pyxicephalus adspersus $(71.86 \pm 0.51-78.47 \pm 1.65 \%)$ and Oreochromis niloticus $(77.03 \pm 0.66-78.95 \pm 3.44 \%$ ) but similar to the range of $2.57-3.59 \%$ found in oysters (Woke et al., 2016). The mean values of carbohydrate recorded in clams in this study were considerably lower than the range of $49.68-58.39 \%$ reported by Woke et al. (2016) in $C$. gasar from the Andoni River but higher than mean values observed by Daniel et al. (2016) in P. adseprsus $(0.54 \pm 0.01-0.64 \pm 0.26 \%)$ and O. niloticus $(1.12 \pm 0.09-$ $1.29 \pm 0.10 \%$ ). However, results of this study were congruent with Swapna and Ravinder (2015) who also reported a similar range of mean carbohydrate values $(4.21-15.67 \%)$ in the bivalve Parreysia cylindrical. Higher mean values of protein were recorded in $S$. senilis in the current study compared to P. adspersus and $O$. niloticus in which mean values varied from $6.41 \pm 0.46-12.04 \pm 0.87 \%$ and $9.03 \pm 2.32-13.53 \pm 0.74 \%$ respectively (Daniel et al., 2016).

Mean values of $\mathrm{Cd}$ recorded in soft tissues of $S$. senilis were in agreement with the range of values reported by Dimari and Hati (2009) in the intestines of Tilapia gallier $(0.09 \pm 0.06 \mu \mathrm{g} / \mathrm{g})$ and Clarias lazera $(0.10 \pm 0.05 \mu \mathrm{g} / \mathrm{g})$ from Lake Alau, Maiduguri, Nigeria while mean $C u$ values obtained were lower than the range of $25.06 \pm 1.56-31.28 \pm 0.78 \mu \mathrm{g} / \mathrm{g}$ reported in tissues of $C$. gasar (Woke et al., 2016). Mean Pb values recorded in soft tissues of clams in this study were congruent with Woke et al. (2016) who also reported a similar range of values in oysters $(0.20 \pm 0.02-0.53 \pm 0.02 \mu \mathrm{g} / \mathrm{g})$ from the same study area. Dimari and Hati (2009) also reported mean $\mathrm{Pb}$ values in gills $(0.48 \pm 0.11-0.53 \pm 0.04 \mu g / g)$, stomach $(0.35 \pm 0.20-0.40 \pm$ $0.02 \mu \mathrm{g} / \mathrm{g})$, intestines $(0.12 \pm 0.01-0.31 \pm 0.16 \mu \mathrm{g} / \mathrm{g})$, and liver $(0.32 \pm 0.12-0.40 \pm 0.03 \mu \mathrm{g} / \mathrm{g})$ of samples of Tilapia gallier, Clarias lazera, and Heterotis niloticus from Lake Alau, Maiduguri, Nigeria. In a study conducted in Volta Estuary, Ghana, Amisah et al. (2009) reported mean Zn concentrations in the range 23 - 42 $\mu \mathrm{g} / \mathrm{g}$ in small-sized clams Galatea paradoxa from the Ada sampling station which were found to be similar to the range of mean values recorded in clams in the present study. However, mean values of $\mathrm{Zn}$ recorded in this 
study were slightly lower than the range $(28.89 \pm 0.53-42.69 \pm 1.81 \mu g / g)$ reported in the mangrove oyster $C$. gasar (Woke et al., 2016).

Taste, appearance, texture, and stability are the quality indicators of sea foods and many other foods. Ash content as well as mineral content provide measures of quality of sea foods. Whereas ash content measures the total amount of minerals present within a sample, mineral content provides a measure of the amount of specific inorganic components present within a sample. Carbohydrates also contribute greatly to the quality (sweetness, appearance, and textural characteristics) of many foods. Carbohydrate and lipid are known to contribute to good food quality. The carbohydrate and lipid contents of clams recorded in this study were thrice greater than those of small-sized clams. It is, therefore, not improbable that large-sized clams will provide better food quality compared to small-sized and medium-sized clams. Size does not seem to affect protein and dietary content of $S$. senilis particularly when the comparison is made between medium-sized and large-sized class.

Variations in $C u$ and $Z n$ contents of $S$. senilis across class size was minimal compared to $C d$ and $P b$. Despite the relatively low content of $P b$ recorded in this study, amount of $P b$ in soft tissues of large-sized clams was 10 times higher than that recorded in small-sized clams. On the other hand, $C u$ content of large-sized clams were only 3 times higher than values obtained in small-sized individuals. Large-sized clams, therefore, have the potential to accumulate higher concentrations of heavy metals in their tissues compared to small-sized and medium-sized individuals. Amisah et al. (2009) also observed relatively higher $\mathrm{Zn}$ concentrations in large-sized individuals of the clam Galatea paradoxa compared to small-sized individuals. In a study conducted to investigate the effects of clam size on heavy metal accumulation in soft tissues of G. paradoxa from the Volta Estuary, Ghana, these workers also reported mean $Z n$ values in large-sized clams that were nearly twice values obtained in small-sized clams during the month of July at the Ada sampling station. Even at very low concentrations, there is considerable variation in heavy metal content of small-sized and large-sized clams. However, the relative significance of these variations in heavy metal content across class size are generally metal-specific as we have seen in results of this study.

\section{Conclusion}

Clams (Senilia senilis) caught by artisanal fishermen at the Andoni River generally fall into three class size distributions: small size $(<30 \mathrm{~mm})$, medium size $(30-50 \mathrm{~mm})$, and large size $(>50 \mathrm{~mm})$. Effect of class size on proximate composition of soft tissues of clams from the Andoni River was more pronounced in carbohydrate and lipid contents but to a small extent in protein and fiber contents. Evidence was lacking that the observed variations in ash and moisture contents of $S$. senilis could be attributed to differences in class sizes of the animals. Mean values of carbohydrate and lipid were generally higher in large-sized clams compared to smallsized and medium-sized clams. The amounts of carbohydrate and lipid in tissues of clams at the Andoni River were, therefore, size-specific.

This was also true of concentrations of $C d$ and $P b$ in soft tissues of the animals. Among the heavy metals, variations in mean $C u$ and $Z n$ levels in soft tissues of $S$. senilis were minimal compared to $C d$ and $P b$ in which large-sized clams also had mean values that were several orders of magnitude higher than small-sized clams. Carbohydrate and lipid are known to contribute to good food quality. The relatively higher amounts of carbohydrate and lipid contents in large-sized clams will invariably suggest better food quality compared to small-sized and medium-sized clams. However, there may also be the cumulative risk of $C d$ and $P b$ uptake in higher trophic levels of the food chain following consumption of large-sized clams, since the concentrations of these heavy metals appear to be higher in soft tissues of large-sized clams compared to small-sized and mediumsized individuals.

[1]. Adeyeye, E. I., Akinyugha, R. J., Febosi, M. E. and Tenabe, V. O. (1996): Determination of some metals in Clarias gariepinus (Cuvier and Valenciemes), Cyprinus carpio (L) and Oreochromis niloticus (L) fishes in a polyculture fresh water pond and their environment. Aquacut., 47: 205-214.

[2]. Allen, S. E., Grimshaw, H. M., Parkinson, J. A., Quarmby, C. (1974). Chemical analysis of ecological materials. Blackwell Scientific Publications. London. 69-90.

[3]. Amisah, S., Adjei-Boateng, D., Obirikorang, K. A. and Quagrainie, K. K. (2009). Effects of clam size on heavy metal accumulation in whole soft tissues of Galatea paradoxa (Born, 1778) from the Volta Estuary, Ghana. International Journal of Fisheries and Aquaculture, 1(2): 14-21.

[4]. Bombata-Fashina, H. A., Megbowon, I., Olumide, O, P. A., Ozor, P. A., Ibrahim, A. O., Adejonwo, O. A. \& Kolade, O. Y. (2013). Comparative study of the proximate composition of some wild tilapiine fishes in Epe Lagoon, Lagos, Nigeria. Journal of Fisheries and Aquatic Science 8(1): 265-267.

[5]. Cagiltay, F., Erkan, N., Selcuk, A., Ozden, O., Devrim Tosun, D., Ulusoy, S. \& Atanasoff, A. (2014). Chemical composition of wild and cultured marsh frog (Rana ridibunda). Bulgarian Journal of Agricultural Science, 20(5): 1250-1254.

[6]. Censi, P., Spoto, S. E., Saiano, F., Sprovieri, M., Mazzola, S., Nardone, G., Di Geronimo, S. I., Punturo, R., and Ottonello, D. (2006). Heavy metals in coastal water systems. A case study from the northwestern Gulf of Thailand. Chemosphere, 64: 11671176. 
[7]. Daniel, U. I., Vincent-Akpu, I. F., Umesi, N. and Togi, P. D. (2016). Comparative study of the proximate composition of Pyxicephalus adspersus and Oreochromis niloticus from Nigerian wetland. International Journal of Current Research, 8(12): 4268042685.

[8]. Dimari, G. A. and S. S. Hati, S. S. (2009). Interaction profile for $\mathrm{As}, \mathrm{Cd}, \mathrm{Cr}$ and $\mathrm{Pb}$ in tissues of fishes (Tilapia gallier, Clarias lazera and Heterotis niloticus). Scientific Research and Essay, 4(9): 894-899.

[9]. El-Shenawy, N. S. (2002). The Effect of metal bioaccumulation on glutathione and lipid perodixation as biomarkers of aquatic ecosystem pollution of Ruditapes decussates and Venerupis pullastra from Lake Timsah, Ismailia. Egypt J. Zool. 39: 475-492.

[10]. Fashina-Bombata, H. and Megbowon, I. (2012). Proximate composition and breeding description of an unidentified cichlid of Epe Lagoon, Lagos, Southwest, Nigeria Commonly Called 'Wesafu'. International Journal of Nutrition and Metabolism, 4(4): 57-63.

[11]. Ferreira, G. A., Machado, A. L. S. and Zalmon, I. R. (2004). Temporal and spatial variation on heavy metal concentrations in the bivalve Perna perna (LINNAEUS, 1758) on the northern coast of Rio de Janeiro State, Brazil. Brazilian Arch. Biol. Technol. 47(2): 319327.

[12]. Fowler, J., Cohen, L. and Jarvis, P. (1998). Practical statistics for field biology. Second Edition. John Wiley and Sons. Chichester, England. pp. 179-209.

[13]. Koh, S. M., Koh, P. K., Sim, K. T., Lee, Y. H. and Surif, S. (2011). Proximate analysis and heavy metal concentrations of tissues of cockles (Anadara granosa) from several cockle farms in Peninsular Malaysia. Sains Malaysiana, 40(2): 139-146.

[14]. Labonne, M., Basin, S., Othman, D. and Luck, J. (2001). Lead isotopes in muscels as tracers of metal sources and water movements in a Lagoon (Thau Basin, S. France). Chemical Geology, 181 (1-4): 181-191.

[15]. Madkour, A., Obirikorang, K. A., Amisah, S., Otchere, F. A. and Adjei-Boateng, D. (2011). Relationship between heavy metal concentrations in bottom sediments and the clam, Galatea Paradoxa (Born 1778) from the Volta Estuary, Ghana. Journal of Environmental Protection, 2: 720-728.

[16]. Murtala, B. A., Abdul, W. O., and Akinyemi, A. A. (2012). Bioaccumulation of heavy metals in fish (Hydrocynus Forskahlii, Hyperopisus Bebe Occidentalis and Clarias Gariepinus) organs in downstream Ogun coastal water, Nigeria. Transnational Journal of Science and Technology, 2(5): 119-133.

[17]. Otchere, F. A. (2003). Heavy metals concentrations and burden in the bivalves (Anadara (Senilia) senilis, Crassostrea tulipa and Perna perna) from lagoons in Ghana: Model to describe mechanism of accumulation/excretion. Afr. J. Biotechnol. 2(9): 280-287.

[18]. Phillips, D. J. H. and Yim, W. W. S. (1981). A comparative evaluation of oysters, mussels and sediments as indicators of trace metals in Hong Kong waters. Mar. Ecol. Prog. Ser. 6: 285-293.

[19]. Swapna, P. and Ravinder, R. T. (2015). Proximate, amino acid, fatty acid and mineral analysis of bivalve Parreysia cylindrica from Waddepally and Kaleshwaram Lake. World Journal of Pharmacy and Pharmaceutical Sciences, 4(4): 1388-1401.

[20]. Udo, P. J. and Arazu, V. N. (2012). The Proximate and mineral composition of two edible crabs Callinectes amnicola and Uca tangeri (Crustecea: Decapoda) of the Cross River, Nigeria. Pakistan Journal of Nutrition, 11 (1): 78-82.

[21]. Woke, G. N., Umesi, N. and Oguzor, N. S. (2016). Effect of size on proximate composition and heavy metal content of the mangrove oyster crassostrea gasar from the Andoni River, Nigeria. Global Journal of Agricultural Research, 4(5): 17-27. 